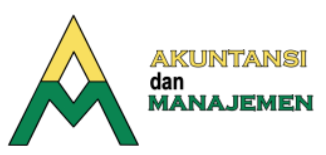

https://akuntansi.pnp.ac.id/jam

e-ISSN 2657-1080, p-ISSN 1858-3687

Akuntansi dan Manajemen

Vol. 16, No.2, 2021, Hal. 33-49

\title{
Faktor-Faktor Yang Mempengaruhi Kepatuhan Wajib Pajak Orang Pribadi
}

\author{
Yulana Wicaksari' ${ }^{1}$, Sartika Wulandari² \\ ${ }^{1} J u r u s a n$ Akuntansi, Universitas Stikubank Semarang \\ Email:ywicaksari@gmail.com \\ ${ }^{2} J u r u s a n$ Akuntansi, Universitas Stikubank Semarang \\ Email: sartikawulan@edu.unisbank.ac.id
}

\begin{abstract}
Purpose of this study was to determine the effect of taxpayer awareness, quality of tax services, tax sanctions, tax knowledge and tax amnesty on individual taxpayer compliance. Sample in this study were 100 individual taxpayers at the Tax Service Office (KPP) in the city of Semarang. Data used in this study is primary data by distributing questionnaires to respondents using google form. Sample selection in this study used accidental sampling using the Slovin formula. After fulfilling the classical assumption test, then the data were analyzed using multiple linear regression analysis techniques. Results showed that taxpayer awareness, tax sanctions, tax knowledge and tax amnesty had a positive effect on individual taxpayer compliance. While the quality of tax services does not affect the compliance of individual taxpayers. Value of the coefficient of determination test with the individual taxpayer compliance value of 41.90 percent can be explained by the research variables. The result of this study can be input for the government what should be done to improve taxpayer compliance.
\end{abstract}

Keywords: Taxpayer Awareness, Tax Service Quality, Tax Sanctions, Tax Knowledge and Tax Amnesty, Taxpayer Compliance

\begin{abstract}
ABSTRAK
Tujuan dalam penelitian adalah untuk mengetahui pengaruh kesadaran wajib pajak, kualitas pelayanan perpajakan, sanksi perpajakan, pengetahuan perpajakan dan pengampunan pajak terhadap kepatuhan wajib pajak orang pribadi. Sampel dalam penelitian ini sebanyak 100 wajib pajak orang pribadi Di Kantor Pelayanan Pajak (KPP) di Kota Semarang. Data yang digunakan dalam penelitian ini adalah data primer dengan cara penyebaran kuesioner kepada responden menggunakan google form. Pemilihan sampel dalam penelitian ini menggunakan accidental sampling menggunakan rumus Slovin. Setelah memenuhi uji asumsi klasik, selanjutnya data dianalisis menggunakan teknik analisis regresi linier berganda. Hasil penelitian menunjukkan bahwa kesadaran wajib pajak, sanksi perpajakan, pengetahuan perpajakan dan pengampunan pajak berpengaruh positif terhadap kepatuhan wajib pajak orang pribadi. Sedangkan kualitas pelayanan perpajakan tidak berpengaruh terhadap kepatuhan wajib pajak orang pribadi. Nilai uji koefisien determinasi dengan nilai kepatuhan wajib pajak orang pribadi sebesar 41,90 persen dapat dijelaskan oleh variabel penelitian. Hasil penelitian ini dapat menjadi masukan bagi pemerintah apa yang harus dilakukan untuk meningkatkan kepatuhan wajib pajak.
\end{abstract}




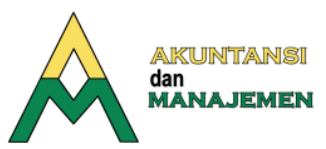

https://akuntansi.pnp.ac.id/jam

e-ISSN 2657-1080, p-ISSN 1858-3687

Kata Kunci: Kesadaran Wajib Pajak, Kualitas Pelayanan Perpajakan, Sanksi Perpajakan, Pengetahuan Pajak dan Amnesti Pajak, Kepatuhan Wajib Pajak

\section{Pendahuluan}

Pajak merupakan sumber penerimaan terbesar dalam APBN negara. Dana dari penerimaan pajak sebagai alokasikan untuk mendanai berbagai pengeluaran negara untuk kemakmuran rakyat. Peranan pajak yang besar membuat pemerintah berupanya meningkatkan penerimaan pajak. Ekstensifikasi ditempuh dengan meningkatkan jumlah wajib pajak yang aktif, sedangkan intensifikasi dapat ditempuh melalui meningkatkan kualitas aparatur perpajakan, pelayanan prima terhadap wajib pajak da pembinaan kepada para wajib pajak, pengawasan administratif, pemeriksaan, penyidikan dan penagihan pasif dan aktif, penegakan hokum serta meningkatkan kepatuhan wajib pajak [1].

Kepatuhan wajib pajak yang tidak menjalankan kewajibannya akan berdampak negatif terhadap Negara dalam bentuk berkurangnnya penerimaan kas Negara [2]. Kepatuhan wajib pajak dapat dilihat dari patuh tidaknya seorang wajib pajak dalam mendaftarkan dirinya, kepatuhan dalam menyetorkan kembali surat pemberitahuan pajak, kepatuhan dalam penghitungan dan pembayaran pajak terutang dan kepatuhan dalam membayar tunggakan. Wajib pajak yang membayar dan melaporkan pajak terutangnya tepat waktu, maka wajib pajak dapat dianggap patuh [3]. Kepatuhan wajib pajak dipengaruhi oleh dua faktor yaitu internal dan eksternal [4].

Semarang - Realisasi penerimaan pajak Kantor Wilayah Direktorat Jenderal Pajak Jawa Tengah I sebesar Rp26,56 triliun rupiah atau 100,17 persen dari rencana target. Penerimaan netto diperkirakan sebesar 3,97 persen namun realisasinya hanya sebesar -3,81 persen. Kepatuhan wajib pajak sebesar 91,73 persen melampaui target sebesar 86 persen dari total wajib pajak SPT tahunan sebanyak 956.225 WP yang menyampaikan SPT [5]. Kanwil DJP Jateng terdapat 8 unit kerja yang mengalami capaian penerimaan hingga 100 persen. Beberapa di antaranya adalah KPP Madya Semarang sebesar 102,95 persen, KPP Pratama Semarang Timur sebesar 111,09 persen, KPP Pratama Pati sebesar 109,34 persen. Pencapaian KPP Pratama Semarang Tengah Dua sebesar 101,74 persen, KPP Pratama Demak sebesar 105,21 persen, KPP Pratama Blora sebesar 106,11 persen, KPP Pratama Jepara sebesar 102,68 persen, dan KPP Pratama Semarang Gayamsari sebesar 101,98 persen. Kantor pajak tercatat mengalami pertumbuhan penerimaan pajak yang positif [6]. Walikota Semarang meminta masyarakat aktif menyampaikan surat pemberitahuan terutang dalam laporan pajak 2020 memanfaatkan aplikasi e-filing dari Direktorat Jendral Pajak karena pajak merupakan sumber pembagunan serta dimanfaatkan dalam penanganan Covid-19 serta mengajak warga semarang memanfaatkan kecangihan teknologi pelaporan SPT Secara online dan dimanapun berada tanpa harus ke kantor pajak [7].

Kesadaran wajib pajak (tax awareness) merupakan perilaku wajib pajak berupa pandangan atau persepsi yang melibatkan keyakinan, pengetahuan dan penalaran serta kecenderungan untuk bertindak sesuai dengan stimulus yang diberikan oleh sistem dan ketentuan perpajakan yang berlaku [8]. Menurut Rahayu kesadaran wajib pajak dalam membayar pajak tepat waktu akan mempengaruhi tinggi rendahnya terhadap kepatuhan wajib pajak. Tingkat kepatuhan wajib pajak untuk menunaikan 


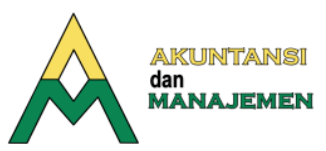

https://akuntansi.pnp.ac.id/jam

e-ISSN 2657-1080, p-ISSN 1858-3687

kewajiban pembayaran pajaknya di Indonesia masih cukup rendah [9]. Salah satu upaya dalam peningkatan kepatuhan wajib pajak adalah memberikan pelayanan yang baik kepada wajib pajak. Peningkatan kualitas dan kuantitas pelayanan diharapkan dapat meningkatkan kepuasan kepada wajib pajak sehingga wajib pajak akan meningkatkan kepatuhan membayar pajak. Kurang responsifnya institusi pelaksana pelayanan pajak akan berdampak pada berkurangnya kepatuhan masyarakat terhadap institusi pelayanan pajak [10].

Sanksi pajak adalah tindakan hukuman yang bersifat memaksa untuk menaati ketentuan undang-undang yang berlaku. Sanksi pajak dibuat bertujuan supaya wajib pajak takut untuk melakukan tindakan melanggar undangundang perpajakan [11]. Setiap jenis pelanggaran pajak mulai dari yang tingkatannya paling kecil sampai yang paling berat sudah tersedia ancaman sanksinya. Hal ini semakin tercermin pasca amandemen undang-undang ketentuan umum dan tata cara perpajakan (UU Nomor 28 Tahun 2007) yang berhasil menggulirkan ketentuan - ketentuan baru menyangkut sanksi seputar pelanggaran kewajiban wajib pajak dan fiskus [9].

Upaya peningkatan kesadaran dan kepedulian harus menjadi perhatian yang utama. Salah satu wujud kesadaran dan kepedulian masyarakat untuk membayar pajak adalah dengan cara mendaftarkan diri sebagai wajib pajak dan membayar pajak sesuai dengan ketentuan perpajakan yang ada, apabila memperoleh atau menerima penghasilan. Oleh karena itu, pengetahuan pajak penting dalam meningkatkan kepatuhan perpajakan.Wajib pajak merasa bahwa keadilan pajak telah diterapkan kepada semua wajib pajak dengan tidak membedakan perlakuan antara wajib pajak badan dengan perorangan, wajib pajak besar dengan wajib pajak kecil dalam artian bahwa semua wajib pajak diperlakukan secara adil maka setiap wajib pajak cenderung untuk menjalankan kewajiban pajaknya dengan baik atau dengan kata lain menimbulkan kepatuhan dalam diri wajib pajak [9]. Salah satu upaya pemerintah dalam meningkatkan kepatuhan wajib pajak adalah dengan diadakannya pengampunan pajak (tax amnesty) [9]. Tax amnesty merupakan penghapusan pajak tetutang yang tidak dikenakan sanksi dan administrasi perpajakan sesuai dengan ketentuan yang diatu dalam Undang-Undang no 11 tahun 2016. Pemberian tax amnesty merupakan upaya pemerintah menarik dana masyarakat yang selama ini parkir di perbankan Negara lain. Kendati demikian, kebijakan ini masih perlu diselaraskan dengan instansi penegak hukum lain [9].

Penelitian yang dilakukan Rahayu menyatakan bahwa pengetahuan perpajakan, sanksi pajak dan tax amnesty berpengaruh positif dan signifikan terhadap kepatuhan wajib pajak [9].Berbeda dengan penelitian Listyowati, Samrotun \& Suhendro yang menyatakan bahwa tax amnesty, sanksi pajak, dan pelayanan pajak tidak berpengaruh terhadap kepatuhan wajib pajak secara signifikan [20]. Sedangkan kesadaran membayar pajak memiliki pengaruh secara signifikan terhadap kepatuhan wajib pajak. Penelitian yang dilakukan Wibowo, Rispantyo \& Widajanti menyatakan bahwa pengetahuan perpajakan, kesadaran wajib pajak, kualitas pelayanan perpajakan, sanksi pajak berpengaruh positif terhadap kepatuhan wajib pajak [10]. Hal disebutkan diatas menjadi dasar penulis untuk utuk melakukan peneitian ini. Berdasarkan uraian-uraian sebelumnya, maka peneliti akan melakukan penelitian tentang pengaruh dari kesadaran wajib pajak, sanksi perpajakan, pengetahuan dan 


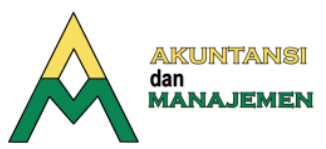

https://akuntansi.pnp.ac.id/jam

e-ISSN 2657-1080, p-ISSN 1858-3687

pemahaman perpajakan dan tak amnesty terhadap kepatuhan wajib pajak pada Kantor Pelayanan Pajak (KPP).

\section{Tinjauan Pustaka}

\section{Theory Of Planned Behavior (TPB)}

Menurut theory of planned behavior, perilaku manusia didasarkan atas tiga jenis pertimbangan yaitu: Behavioral beliefs (keyakinan perilaku), yaitu keyakinan tentang kemungkinan hasil dari perilaku dan evaluasi atas hasil tersebut (beliefs strength and outcome evaluation). Keyakinan perilaku menghasilkan sikap terhadap perilaku baik atau buruk; Normative beliefs (keyakinan normatif), yaitu keyakinan tentang harapan normatif orang lain dan motivasi untuk memenuhi harapan tersebut (nomative beliefs and motivation to comply). Keyakinan normatif mengakibatkan tekanan social yang dirasakan atau norma subyektif (subjective norm); dan Control beliefs (keyakinan kontrol), yaitu keyakinan tentang adanya faktor yang dapat memfasilitasi atau menghambat perilaku yang akan ditampilkan (control beliefs) dan persepsi tentang seberapa kuat faktor tersebut (perceived power). Keyakinan control menimbulkan kontrol keperilakuan yang dipersepsikan [12].

Relevansi dari theory of planned of behavior dengan penelitian ini adalah bahwa perilaku patuh atau tidak patuh wajib pajak dalam memenuhi kewajiban perpajakannya dipengaruhi oleh niat yang dimiliki oleh wajib pajak. Apabila wajib pajak memiliki niat untuk patuh terhadap kewajiban perpajakannya maka akan terjadiperilaku tax compliance (kepatuhan pajak). Dimana niat untuk patuh ditentukan oleh tiga faktor yaitu sikap, norma subyektif dan control keperilakuan yang dipersepsikan yang dimiliki oleh wajib pajak [12].

\section{Kepatuhan Wajib Pajak}

Menurut Kamus umum Bahasa Indonesia, istilah kepatuan adalah "Kepatuhan berarti tunduk atau patuh pada ajaran dalam perpajakan, kita dapat memberi pengertian bahwa kepatuhan perpajakan merupakan ketaatan, tunduk, dan patuh, serta melaksanakan ketentuan perpajakan [13]. Menurut Rahman kepatuhan perpajakan dapat didefinisikan sebagai keadaan di mana Wajib Pajak memenuhi semua kewajiban perpajakan dan melaksanakan hak perpajakannya [18]. Wajib pajak dikatakan patuh apabila tepat waktu dalam penyampain surat pemberitahuan, tidak mempunyai tunggakan untuk semua jenis pajak, tidak pernah dijatuhi hukuman pidana dan menyelenggarankan pembukuan \& audit dalam dua tahun pajak terakhir [1].

\section{Kesadaran Wajib Pajak}

Menurut Rahma kesadaran Wajib Pajak adalah keadaan ketika wajib pajak yang tanpa paksaan dari pihak manapun untuk membayar pajaknya sesuai dengan peraturan yang berlaku" [14]. Kesadaran wajib pajak (tax awareness) merupakan perilaku wajib pajak berupa pandangan atau persepsi yang melibatkan keyakinan, pengetahuan dan penalaran serta kecenderungan untuk bertindak sesuai dengan stimulus yang diberikan oleh sistem dan ketentuan perpajakan yang berlaku [8]. Kesadaran wajib pajak adalah suatu kondisi dimana wajib pajak mengetahui, memahami dan 


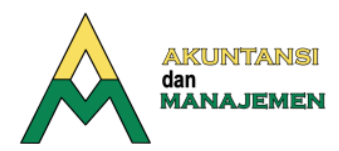

https://akuntansi.pnp.ac.id/jam

e-ISSN 2657-1080, p-ISSN 1858-3687

melaksanakan ketentuan perpajakan dengan benar dan sukarela. Dalam meningkatkan kepatuhan wajib pajak diperlukan adanya kesadaran perpajakan dari wajib pajak. ileh sebab itu, kesadaran wajib pajak diduga berpengaruh terhadap kepatuhan wajib pajak [13].

\section{Kualitas Pelayanan Perpajakan}

Pelayanan pajak menurut Boediono adalah suatu proses bantuan kepada wajib pajak dengan cara-cara tertentu yang memerlukan kepekaan dan hubungan interpersonal agar terciptanya kepuasan dan keberhasilan [15]. Untuk menciptakan kualitas, pelayanan harus diproses secara terus-menerus dan prosesnya mengikuti jarum jam, yaitu dimulai dari apa yang dilakukan, menjelaskan bagaimana mengerjakannya, memperlihatkan bagaimana cara mengerjakan, diakhiri dengan menyediakan pembimbingan, dan mengoreksi, sementara mereka mengerjakan. Kualitas pelayanan yang baik terhadap wajib pajak merupakan cara untuk meningkatkan kepatuhan wajib pajak dalam membayar kewajiban perpajakannya. Berdasarkan pemaparan di atas, kualitas pelayanan perpajakan dapat dijelaskan sebagai persepsi konsumen terhadap perbedaan antara pelayanan yang diharapkan dari kantor perpajakan atau petugas perpajakan dengan kinerja aktual yang ada [10].

\section{Sanksi Pajak}

Sanksi adalah suatu tindakan berupa hukuman yang diberikan kepada orang yang melanggar peraturan. Peraturan atau Undang-undang merupakan rambu-rambu bagi seseorang untuk melakukan sesuatu mengenai apa yang harus dilakukan dan apa yang seharusnya tidak dilakukan [13]. Sanksi perpajakan dapat dikatakan jaminan peraturan perundang-undangan perpajakan (norma perpajakan) akan dituruti/ditaati/dipatuhi oleh wajib pajak untuk tidak melakukan tindakan melanggar norma perpajakan [10]. Sebagaiamana dimaklumi suatu kebijakan berupa pengenaan sanksi dapat dipergunakan untuk 2 (dua) maksud, yang pertama adalah untuk mendidik dan yang kedua adalah untuk menghukum. Mendidik dimaksudkan agar mereka yang dikenakan sanksi akan menjadi lebih baik dan lebih mengetahui hak dan kewajibannya sehingga tidak lagi melakukan kesalahan yang sama. Maksud yang kedua adalah untuk menghukum sehingga pihak yang terhukum akan menjadi jera dan tidak lagi melakukan kesalahan yang sama. Peraturan atau Undang-Undang merupakan rambu-rambu bagi seseorang untuk melakukan sesuatu mengenai apa yang harus dilakukan dan apa yang seharusnya tidak dilakukan. Sanksi diperlukan agar peraturan atau Undang-Undang tidak dilanggar [10].

\section{Pengetahuan Perpajakan}

Gunadi mengungkapkan bahwa pengetahuan wajib pajak terhadap peraturan perundang-undangan perpajakan yang berlaku berpengaruh positif terhadap tingkat kepatuhan wajib pajak, di mana pengetahuan wajib pajak terhadap peraturan perundang-undangan perpajakan yang berlaku sangatlah penting untuk dapat melaksanakan dan memenuhi kewajiban perpajakan [16]. Pengetahuan perpajakan tersebut akan membantu kepatuhan wajib pajak dalam membayar pajak, sehingga 


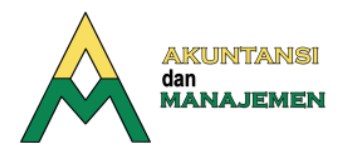

https://akuntansi.pnp.ac.id/jam

e-ISSN 2657-1080, p-ISSN 1858-3687

tingkat kepatuhan akan meningkat. Menurut Rahayu Wajib pajak yang berpengetahuan tentang pajak, secara sadar diri akan patuh membayar pajak. Mereka telah mengetahui bagaimana alur penerimaan pajak tersebut akan berjalan, hingga akhirnya manfaat membayar pajak tersebut dirasakan [9]. Seorang wajib pajak akan taat membayar pajak apabila wajib pajak mempunyai pengetahuan tentang perpajakan dengan baik. Apabila wajib pajak mengetahui peraturan pajak, maka wajib pajak tersebut akan taat melaksanakan kewajiban perpajakannya dan akan meningkatkan kepatuhan wajib pajak [9].

\section{Tax Amnesty}

Tax Amnesty adalah istilah yang digunakan untuk menggambarkan penawaran satu kali untuk menyelesaikan hutang pajak yang beredar dengan jumlah yang kurang dari hutang saat ini. Dengan kata lain, pendekatan ini berarti memungkinkan pembayar pajak untuk membayar hutang pajak yang belum dibayar dalam keadaan yang sesuai tanpa menimbulkan biaya keterlambatan tambahan dan denda lainnya [13]. Menurut Waluyo pengampunan pajak adalah kebijakan pemerintah di bidang perpajakan dalam bentuk pengampunan pajak terhadap wajib pajak dengan memberi penghapusan pajak yang terutang oleh wajib pajak selama tahun pajak [17]. Tujuan utama pengampunan pajak yaitu meningkatkan kepatuhan wajib. pajak (tax compliance) dan meningkatkan penerimaan penerimaan Negara [17]. Menurut PMK No. 118/PMK.03/2016 tax amnesty adalah adalah penghapusan pajak yang seharusnya terutang, tidak dikenai sanksi administrasi perpajakan dan sanksi pidana di bidang perpajakan, dengan cara mengungkap Harta dan membayar Uang Tebusan sebagaimana diatur dalam UndangUndang Pengampunan Pajak [3].

\section{Model Penelitian Dan Hipotesis}

\section{Pengaruh Kesadaran Wajib Pajak Terhadap Kepatuhan Wajib Pajak}

Kesadaran wajib pajak merupakan perilaku wajib pajak berupa pandangan atau persepsi yang melibatkan keyakinan, pengetahuan dan penalaran serta kecenderungan untuk bertindak sesuai dengan stimulus yang diberikan oleh system dan ketentuan perpajakan yang berlaku [8]. Kesadaran wajib pajak merupakan variabel dari faktor internal yang diprediksikan berpengaruh terhadap kepatuhan wajib pajak. Wajib pajak yang mempunyai kesadaran terhadap kewajiban perpajakan akan mengakui, menghargadi dan ada kemauan untuk memenuhi kewajiban perpajakannya. Dengan kesadaran wajib pajak yang tinggi, maka tingkat kepatuhan wajib pajak juga tinggi [18]. Penelitian yang dilakukan Perdana \& Dwirandra menyatakan bahwa kesadaran wajib pajak memiliki pengaruh positif secara signifikan terhadap kepatuhan wajib pajak [4]. Berdasarkan kerangka pemikiran diatas maka hipotesis pertama dalam penelitian ini adalah sebagai berikut:

\section{$H_{1}$ : Kesadaran wajib pajak berpengaruh positif terhadap kepatuhan wajib pajak}

\section{Pengaruh Kualitas Pelayanan Perpajakan Terhadap Kepatuhan Wajib Pajak}

Menurut Tjiptono dan Chandra, kualitas pelayanan merupakan tingkatan kondisi baik buruknya sajian yang diberikan oleh perusahaan jasa dalam rangka memuaskan konsumen dengan cara memberikan atau menyampaikan jasa yang melebihi harapan 


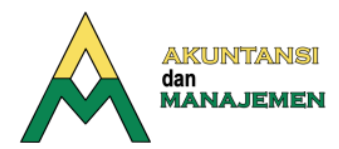

https://akuntansi.pnp.ac.id/jam

e-ISSN 2657-1080, p-ISSN 1858-3687

konsumen. Pelayanan pajak berkaitan erat dengan petugas pajak (fiskus) [19]. Petugas pajak memberikan pelayanan yang maksimal dalam membantu mengurus dan memberikan informasi tentang kebutuhan wajib pajak dalam rangka penyelesaikan kewajiban perpajakan. Penelitian Wibowo, Rispantyo \& Widajanti menyatakan bahwa kualitas pelayanan pajak berpengaruh positif dan signifikan terhadap kepatuhan wajib pajak [10]. Berdasarkan kerangka pemikiran diatas maka hipotesis kedua dalam penelitian ini adalah sebagai berikut:

$\mathrm{H}_{2}$ : Kualitas Pelayanan Perpajakan berpengaruh positif terhadap kepatuhan wajib pajak

\section{Pengaruh Sanksi Perpajakan Terhadap Kepatuhan Wajib Pajak}

Sanksi perpajakan dapat dikatakan jaminan peraturan perundang-undangan perpajakan (norma perpajakan) akan dituruti/ditaati/dipatuhi oleh wajib pajak untuk tidak melakukan tindakan melanggar norma perpajakan [10]. Sanksi pajak diberlakukan dengan tujuan agar wajib pajak dapat mematuhi dan melaksanakan kewajiban perpajakannya dengan benar. Selain itu, petugas pajak perlu menegakkan hukum secara adil sehingga dapat memotivasi wajib pajak untuk taat dan patuh dalam memenuhi kewajibannya. Sanksi yang tegas dapat meningkatkan kesadaran wajib pajak [20]. Semakin tegas sanksi yang diberlakukan maka akan meningkatkan kepatuhan wajib pajak. Berdasarkan Teori Perilaku Terencana (Theory of Planned Behavior), sanksi perpajakan berkaitan dengan control belief dalam hal mendorong seseorang dalam mematuhi aturan yang berlaku. Wajib pajak akan mematuhi kewajiban perpajakannya apabila sanksi yang diberikan lebih merugikan wajib pajak tersebut. Penelitian yang dilakukan Anggraini, Yuesti \& Sudiartana menyatakan bahwa sanksi perpajakan berpengaruh positif terhadap kepatuhan wajib pajak [1]. Berdasarkan kerangka pemikiran diatas maka hipotesis tiga dalam penelitian ini adalah sebagai berikut:

\section{H3: Sanksi Perpajakan berpengaruh positif terhadap kepatuhan wajib pajak}

\section{Pengaruh Pengetahuan Perpajakan Terhadap Kepatuhan Wajib Pajak}

Pengetahuan perpajakan merupakan informasi pajak yang dapat digunakan wajib pajak sebagai dasar untuk bertindak, mengambil keputusan, dan untuk menempuh arah atau strategi tertentu sehubungan dengan pelaksanaan hak dan kewajibannya di bidang perpajakan [10]. Sehingga seiring dengan meningkatnya pengetahuan perpajakan yang dimiliki wajib pajak dapat mempengaruhi patuh tidaknya wajib pajak karena wajib pajak sudah mengetahui atas konsekuensi maupun sanksi yang yang bisa dikenakan jika mereka tidak melaksanakan kewajibannya dengan benar [3]. Penelitian Wibowo, Rispantyo \& Widajanti menyatakan bahwa pengetahuan perpajakan berpengaruh positif dan signifikan terhadap kepatuhan wajib pajak [10]. Berdasarkan kerangka pemikiran diatas maka hipotesis empat dalam penelitian ini adalah sebagai berikut:

$H_{4}$ : Pengetahuan Perpajakan berpengaruh positif terhadap kepatuhan wajib pajak 


\section{Pengaruh Tax Amnesty Terhadap Kepatuhan Wajib Pajak}

Tax amnesty adalah kebijakan pemerintah tentang perpajakan yang menyebabkan wajib pajak mendapat pengampunan pajak [17]. Wajib pajak yang mengungkapkan hartanya dan membayar tebusan akan mendapat penghapusan pajak yang seharusnya terutang, tidak akan dikenakan sanksi administrasi dan sanksi pidana. Pemerintah pada awalnya memberlakukan tax amnesty dengan harapan dapat menarik dana masyarakat yang selama ini berada di perbankan luar negeri [20]. Wajib pajak yang tidak mengikuti tax amnesty dan kemudian ditemukan bahwa adanya harta bersih yang tidak dilaporkan, maka harta bersih tersebut akan diperlakukan sebagai penghasilan sehingga akan dikenai pajak dan sanksi sesuai undang-undang perpajakan yang berlaku. Wajib pajak yang mengikuti tax amnesty dan mendapat pengampunan pajak akan meningkatkan kepatuhannya [9). Penelitian yang dilakukan Sari \& Fidiana menyatakan bahwa tax amnesty berpengaruh positif terhadap kepatuhan wajib pajak [3]. Berdasarkan kerangka pemikiran diatas maka hipotesis lima dalam penelitian ini adalah sebagai berikut:

\section{H5: Tax amnesty berpengaruh positif terhadap kepatuhan wajib pajak}

\section{Model Penelitian}

Berdasarkan latar belakang dan tinjauan pustaka diatas tentang faktor-faktor yang mempengaruhi kepatuhan wajib pajak, maka penelitian ini menggunakan model penelitian berikut ini:

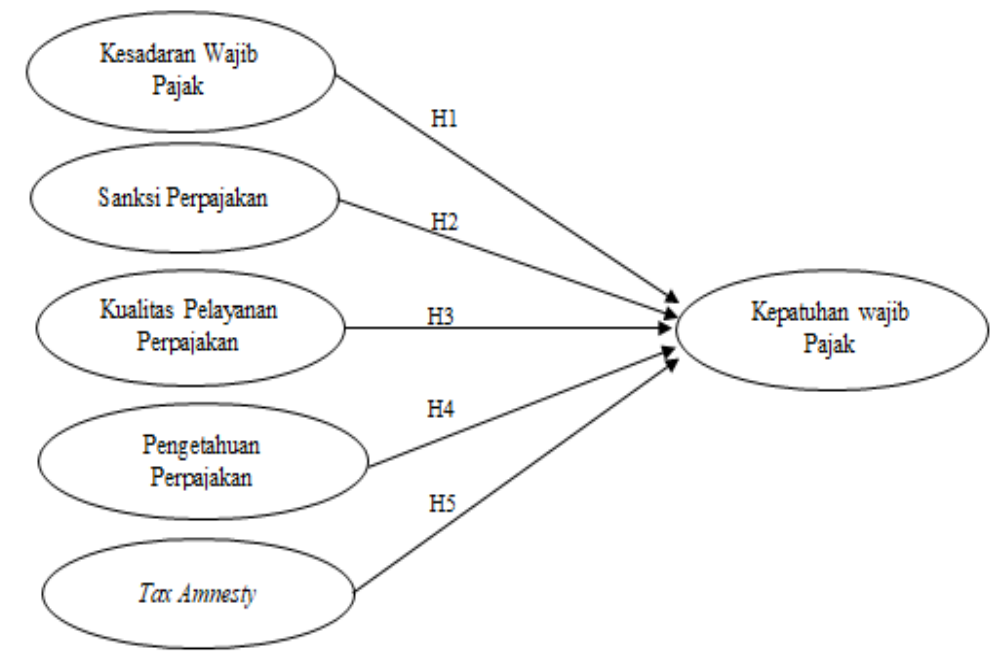

\section{Metode Penelitian}

\section{Populasi dan Sampel}

Populasi merupakan bentuk umum berupa obyek atau subyek dengan kualitas dan karakteristik yang telah ditetapkan oleh peneliti. Obyek atau subyek tersebut untuk selanjutnya dilakukan penelitian untuk mengetahui hasilnya [22]. Populasi dalam penelitian ini adalah wajib pajak yang terdaftar Kantor Pelayanan Pajak di Kota Semarang. Sampel merupakan bagian dari jumlah dan karakteristik populasi. Sampel dibutuhkan jika populasi yang akan diteliti memiliki jumlah yang besar dan peneliti tidak mampu meneliti semuanya karena beberapa alasan, seperti halnya keterbatasan 


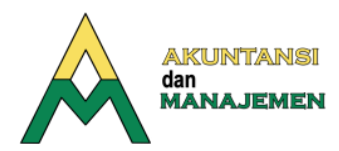

https://akuntansi.pnp.ac.id/jam

e-ISSN 2657-1080, p-ISSN 1858-3687

dana, tenaga kerja, dan waktu [22]. Pada penelitian ini, mengunakan teknik Accidental sampling dengan mengunakan rumus Slovin dengan rumus:

$$
n=\frac{N}{\left(N \cdot e^{2}+1\right)}
$$

Keterangan:

$$
\begin{aligned}
n= & \text { Jumlah sampel } \\
\mathrm{N}= & \text { Jumlah polulasi } \\
\mathrm{e}= & \text { Presentase kelongaran ketidaktelitian karena kesalahan pengambilan } \\
& \text { sampel yang masih dapat ditolerir yaitu 10\% }
\end{aligned}
$$

Jenis Data dan Teknik Pengumpulan Data

Jenis data yang digunakan dalam penelitian ini adalah data primer. Data primer dalah data yang pertama kali dicatat dan dikumpulkan oleh peneliti. Data primer ini berasal dari jawaban responden melalui kuesioner penelitian [22]. Dalam hal ini data yan g digunakan adalah dari hasil jawaban responden atas pertanyaan yang diajukan kepada wajib pajak orang pribadi di Kota Semarang dengan cara memberikan Kuesioner atau google forms.

\section{Teknik Pengumpulan Data}

Menurut Sugiono metode pengumpulan data merupakan langkah paling stategis dalam penelitian karena tujuan utama dari penelitian adalah pengumpulan dana tanpa mengetahui metode pengumpulan data, maka meneliti tidak akan mendapatkan data yang memenuhi standar data yang ditetapkan [22]. Jenis data yang digunakan dalam penelitian ini adalah data primer dengan metode survei. Pertanyaan peneliti dan jawaban responden dapat dikemukakan secara tertulis melalui sebuah kuesioner. Teknik ini memberikan tanggung jawab kepada responden untuk membaca dan menjawab pertanyaan [23]. Pertanyaan dalam penelitina ini merupakan pertanyaan Skala Likert.

\section{Pengukuran Variabel \\ Variabel Dependen}

Variabel dependen adalah tipe variabel yang dijelaskan atau dipengaruhi oleh variabel independen. Penjelasan dan prediksi fenomena secara sistematis digambarkan dengan variabilitas variabel-variabel dependen yang dijelaskan atau dipengaruhi oleh variabel-variabel independen [23].

Kepatuhan perpajakan dapat didefinisikan sebagai "suatu keadaan dimana wajib pajak memenuhi semua kewajiban perpajakan dan melaksanakan hak perpajakannya" [21]. Pengukuran variabel ini akan disusun dalam kuesioner yang disusun dengan Skala Likert. Pengukuran variabel ini mengadopsi penelitian Listyowati, et.al [20]. Pengukuran dilakukan dengan aspek wajip pajak memiliki NPWP dan mampu melakan perhitungan, pengisian, pelaporan SPT serta melakukan pembayaran pajak.

Variabel Independen adalah tipe variabel yang menjelaskan atau mempengaruhi variabel lain [23]. Sedangkan menurut Sugiyono, variabel independen 


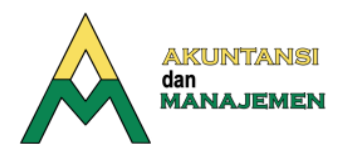

https://akuntansi.pnp.ac.id/jam

e-ISSN 2657-1080, p-ISSN 1858-3687

sering disebut sebagai variabel simulus, predictor, antecedent [22]. Pengukuran variabel ini akan disusun dalam kuesioner yang disusun dengan Skala Likert.

Kesaran wajib pajak diukuran variabel ini mengadopsi penelitian Listyowati, et.al [20]. Pengukuran variabel meliputi pengetahuan wajib pajak tentang manfaat pajak bagi pembangunan, penetapan serta sifat pajak dan akibat tidak membayar pajak.

Sanksi perpajakan diukur variabel ini akan disusun dalam kuesioner yang disusun dengan Skala Likert. Pengukuran variabel ini mengadopsi penelitian Listyowati, et.al [20]. Pengukuran variabel ini meliputi sanksi diberikan terhadap pelanggaran pajak dari sanksi administrasi hingga pidana sesuai dengan peraturan yang berlaku.

Kualitas pelayanan perpajakan diukur variabel ini akan disusun dalam kuesioner yang disusun dengan Skala Likert. Pengukuran variabel ini mengadopsi penelitian Listyowati, et.al [20]. Pengukuran variabel tentang sikap petugas pajak dalam melakukan pelayanan secara ramah, sopan serta tanggap dalam memberikan informasi perpajakan.

Pengetahuan perpajakan diukur variabel ini akan disusun dalam kuesioner yang disusun dengan Skala Likert. Pengukuran variabel ini mengadopsi penelitian Anggrarini, et.al [1]. Pengukuran variabel ini antara lain mengenai wajib pajak mengetahui ketantuan perpajakan, fungsi pajak serta mengetahui fungsi NPWP bagi wajib pajak dan keuntungan tidak dilakukan pemeriksaan oleh petugas.

Tax amnesty diukur variabel ini akan disusun dalam kuesioner yang disusun dengan Skala Likert. Pengukuran variabel ini mengadopsi penelitian Listyowati, et.al [20]. Pengukuran tax amnesty meliputi pengertian, perhitungan serta manfaat dari adanya tax amnesty yang dilakukan.

\section{Metode Analisis Data}

Analisis data hipotesis yang telah diajukan pada penelitian ini, selanjutnya akan dianalisis dengan menggunkan analisis statistik deskriptif, uji kualitas data, uji normalitas, uji asumsi klasik yaitu multikolinearitas, heteroskedastisitas, dan autokorelasi dilakukan untuk menguji kelayakan model regresi yang selanjutnyaakan digunakan untuk menguji hipotesis penelitian. Uji hipotesis dilakukan untuk menguji apakah semua variabel independen yang dimasukkan dalam model mempunyai pengaruh secara bersama-sama terhadap variabel dependen dan perluasan dari analisis regresi linier berganda.

\section{Analisis Regresi Linier Berganda}

Analisis regresi berganda digunakan untuk mengetahui pengaruh antara variabel bebas dalam mempengaruhi variabel tidak bebas secara bersama-sama ataupun secara parsial. Persamaan regresi dengan linier berganda dalam penelitian ini adalah:

$$
\mathrm{Y}=a+\mathrm{b}_{1} \mathrm{X} 1+\mathrm{b}_{2} \mathrm{X} 2+\mathrm{b}_{3} \mathrm{X} 3+\mathrm{b}_{4} \mathrm{X} 4+\mathrm{b}_{4} \mathrm{X} 5+e
$$

Dimana:

$\mathrm{Y} \quad=$ Kepatuhan Wajib Pajak

$a \quad=$ konstan 


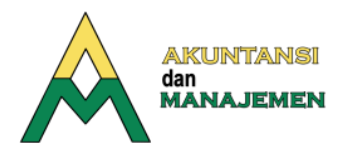

https://akuntansi.pnp.ac.id/jam

e-ISSN 2657-1080, p-ISSN 1858-3687

$\mathrm{b} \quad=$ Koefisien Regresi

$\mathrm{X} 1=$ Kesadaran Wajib Pajak

$\mathrm{X} 2=$ Sanksi Perpajakan

$\mathrm{X} 3=$ Kualitas Pelayanan Perpajakan

X4 = Pengetahuan Perpajakan

X5 = Tax Amnesty

$\varepsilon \quad=$ Error

\section{Hasil Dan Pembahasan}

\section{Gambaran Umum Responden}

Responden dalam penelitian ini adalah wajib pajak orang pribadi di Kantor Pelayanan Pajak (KPP) Di Kota Semarang. Sampel dalam peneitian ini sebanyak 100 responden wajib pajak yang dilakukan dengan menggunakan google form.

\section{Uji Kualitas Data}

\section{Uji Validitas}

Uji validitas digunakan untuk mengukur sah atau valid tidaknya suatu kuesioner. Uji signifikan dilakukan dengan membandingkan nilai r-hitung dengan nilai r-tabel untuk degree of freedom ( $d f$ ) $=\mathrm{n}-2$ ( $\mathrm{n}$ adalah jumlah sampel) [24]. Dengan jumlah sampel (n) adalah 100 dan tingkat signifikansi 0,05 maka nilai r-tabel pada penelitian ini adalah 0,165 . Hasil pengujian seluruh pertanyaan pada variabel kesaran wajib pajak $\left(X_{1}\right)$ dengan 5 item pernyataan, sanksi perpajakan $\left(X_{2}\right)$ dengan 6 item pernyataan, kualitas pelayanan perpajakan $\left(\mathrm{X}_{3}\right)$ dengan 6 item pernyataan, pengetahuan perpajakan $\left(\mathrm{X}_{4}\right)$ dengan 4 item pernyataan, tax amnesty $\left(\mathrm{X}_{5}\right)$ dengan 7 item pernyataan, kepatuhan wajib pajak orang pribadi $(\mathrm{Y})$ dengan 6 item pernyataan dinyatakan valid karena nilai masing-masing item pernyataan memiliki nilai yang lebih besar dari 0,165.

\section{Uji Reabilitas}

Uji reliabilitas dilakukan terhadap item pertanyaan yang dinyatakan valid. Uji reliabilitas digunakan untuk mengukur konsistensi jawaban responden. Berdasarkan hasil reliabilitas trehadap masing-masing variabel menunjukan nilai yang konsisten untuk kesadaran wajib pajak sebesar 0,754 , sanksi perpajakan sebesar 0,753 , kualitas layanan perpajakan sebesar 0,848, pengetahuan perpajakan sebesar 0,852 , tax amnesti sebesar 0,842 dan kepatugan wajib pajak orang pribadi sebesar 0,832. Dapat diketahui bahwa nilai koefisien Cronbach's Alpha pada masing-masing variabel $>0,70$.

\section{Uji Asumsi Klasik}

Hasil uji asumsi klasik yang terkait dengan uji normalitas menunjukkan bahwa nilai skewness sebesar dibahwa $<1,96$ dan nilai kurtosis sebesar dibawah $<1,96$, dengan demikian dapat di simpulkan bahwa data yang diolah memenuhi asumsi normalitas. Begitu pula asumsi multikoliniaritas menunjukkan bahwa semua variabel memiliki nilai tolerance lebih besar dari 0,10 dan nilai Variance Inflation Factor (VIF) lebih kecil 


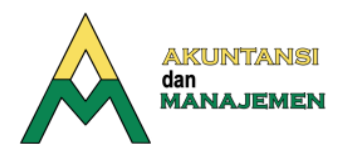

https://akuntansi.pnp.ac.id/jam

e-ISSN 2657-1080, p-ISSN 1858-3687

dari 10. Sehingga pada model regresi yang digunakan dalam penelitian ini tidak terjadi multikolonieritas. Hasil uji menunjukan bahwa pengujian heterokedastisitas menggunakan uji Glejser diperoleh nilai signifikansi masing-masing variabel diatas 0,05 . Dengan demikian dapat disimpulkan bahwa model regresi tidak terjadi heterokedastisitas.

\section{Analisis Regresi Linier Berganda}

Analisis regresi berganda dimaksudkan untuk menguji pengaruh simultan dari beberapa variabel independen terhadap satu variabel dependen. Hasil uji dapat diperoleh persamaan matematis regresi linear berganda pada model pertama dalam penelitian ini, sebagai berikut:

Kepatuhan Wajib Pajak Orang Pribadi $=-0,308+0,437 \mathrm{KWP}+0,157 \mathrm{SP}+0,099 \mathrm{KPP}$ $+0,278 \mathrm{PP}+0,208 \mathrm{TA}$

\section{Uji Koefisien Determinasi}

Hasil uji koefisien determinasi menunjukan bahwa adjusted $\mathrm{R}^{2}$ sebesar 0,419 . Hal ini berarti bahwa 41,90 persen kepatuhan wajib pajak orang pribadi dapat dijelaskan oleh kesadaran wajib pajak, sanksi perpajakan, kualitas pelayanan perpajakan, pengetahuan perpajakan, tax amnesty sedangkan 58,10 persen kepatuhan wajib pajak dijelaskan oleh variabel atau sebab-sebab lainnya diluar model.

\section{Uji Statistik F}

Hasil pengujian nilai F hitung untuk pengaruh variabel jumlah kesadaran wajib pajak, sanksi perpajakan, pemahaman perpajakan dan tax amnesty terhadap kepatuhan wajib pajak orang pribadi diperoleh nilai $F$ hitung sebesar 15,268 dengan nilai signifikansi sebesar 0,000, memberikan pengertian bahwa model regresi pada variabel penelitian tergolong fit atau baik sehingga dapat digunakan memprediksi penelitian selanjutnya.

\section{Pembahasan}

\section{Pengaruh Kesadaran Wajib Pajak Terhadap Kepatuhan Wajib Pajak Orang Pribadi}

Kesadaran wajib pajak berpengaruh positif terhadap kepatuhan wajib pajak. Kesadaran wajib pajak mengetahui bahwa membayar pajak bentuk pengabdian kepada negara akan meningkatkan kepatuhan wajib pajak dalam membayar pengasilan terutang secara tepat waktu. Wajib pajak mengetahui bahwa penundaan dan membayaran pajak tidak sesuai dengan akan dapat menggangu dan merugian negara dalam pembangunan nasional. Berdasarkan teori ini, kesadaran wajib pajak berkaitan dengan behavior belief yang menjelaskan bahwa kesadaran membayar pajak tinggi maka akan meningkatkan kemauan wajib pajak dalam membayarkan pajaknya sehingga akan meningkatkan penerimaan pajak Negara. Penelitian ini sejalan dengan penelitian Anggarini, Yuesti \& Sudiartana menyatakan bahwa kesadaran wajib pajak berpengaruh positif terhadap kepatuhan wajib pajak [1]. Serta didukung dengan 


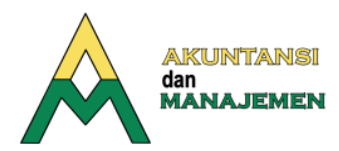

https://akuntansi.pnp.ac.id/jam

e-ISSN 2657-1080, p-ISSN 1858-3687

penelitian Perdana \& Dwirandra, juga menyatakan bahwa kesadaran wajib pajak berpengaruh signifikan dan positif terhadap kepatuhan wajib pajak [4].

\section{Pengaruh Sanksi Perpajakan Terhadap Kepatuhan Wajib Pajak Orang Pribadi}

Sanksi perpajakan berpengaruh positif terhadap kepatuhan wajib pajak. Pemberian saksi dalam bentuk administrasi atau pidana terkait pelanggaran aturan perpajakan akan meningkatkan kepatuhan wajib pajak dalam melakukan pembayaran pajak. Sansi pajak dikenakan kepada pelanggar perpajakan tanpa ada tolerasi akan membuat wajib pajak melakukan pembayaran pajak pengasilan terutang dilakukan tepat waktu. Wajib pajak akan mematuhi kewajiban perpajakannya apabila sanksi yang diberikan lebih merugikan wajib pajak tersebut yang akan meningkatkan kepatuhan wajib pajak. Penelitian ini sejalan dengan penelitian penelitian Perdana \& Dwirandra sanksi perpajakan berpengruh positif pada kepatuhan wajib pajak [4]. Berbeda dengan penelitian Listyowati, Samrotun \& Suhendro menyatakan bahwa sanksi perpajakan tidak memiliki pengaruh terhadap kepatuhan wajib pajak [20].

\section{Pengaruh Kualitas Pelayanan Perpajakan Terhadap Kepatuhan Wajib Pajak Orang Pribadi}

Kualitas pelayanan perpajakan tidak berpengaruh terhadap kepatuhan wajib pajak. Kepatuhan wajib pajak tidak dipengaruhi oleh sikap pelayan pajak. Wajib pajak melaksanakan kewajiban perpajakannya karena sadar pajak telah ditetapkan dalam undang-undang perpajakan yang berlaku. Sehingga dapat disimpulkan bahwa kemampuan petugas pajak dalam memberikan informasi perpajakan secara mudah dimengerti dan memberikan pelayanan pajak secara cepat tidak akan mempengaruhi kepatuhan wajib pajak. Penelitian ini sejalan dengan penelitian Listyowati, Samrotun \& Suhendro kualitas pelayanan perpajakan tidak berpengaruh terhadap kepatuhan wajib pajak [20]. Tetapi tidak sejalan dengan Wibowo, Rispanto \& Widajanti menyatakan bahwa kuaitas pelayanan perpajakan berpengaruh terhadap kepatuhan wajib pajak [10].

\section{Pengaruh Pengetahuan Perpajakan Terhadap Kepatuhan Wajib Pajak Orang Pribadi}

Pengetahuan perpajakan berpengaruh positif terhadap kepatuhan wajib pajak. Hal ini sejalan dengan keinginan pemerintah menganut self assesment system yang menuntut wajib pajak untuk memiliki pengetahuan terkait peraturan perpajakan. Wajib pajak mengetahui cara menghitung, melaporkan dan menyetorkan pajaknya sendiri akan membuat wajib pajak membayar pajak secara tepat waktu. Pengetahuan perpajakan yang memadai wajib pajak dapat mengetahui dan dengan mudah melaksanakan kewajiban yang harus dilakukannya dalam hal perpajakan. Semakintinggi tingkat pengetahuan yang dimiliki wajib pajak maka akan meningkatkan kepatuhan wajib pajak. Penelitian ini sejalan dengan penelitan Rahayu menyatakan bahwa pengetahuan perpajakan berpengaruh positif terhadap kepatuhan wajib pajak [9]. Serta didukung dengan penelitian Sari \& Fidiana, pengetahuan perpajakan yang dimiliki oleh wajib pajak diharapkan dapat meningkatkan kepatuhan wajib pajak [3]. 


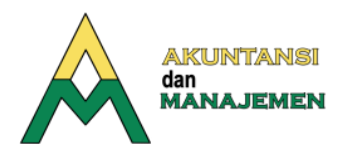

https://akuntansi.pnp.ac.id/jam

e-ISSN 2657-1080, p-ISSN 1858-3687

\section{Pengaruh Tax Amnesty Terhadap Kepatuhan Wajib Pajak Orang Pribadi}

Tax amnesty berpengaruh positif terhadap kepatuhan wajib pajak. Pelaksanaan tax amnesty yang berlangsung mampu memberikan stimulus kepada wajib pajak untuk meningkatkan kepatuhan perpajakan. Wajib pajak mengetahui perhitungan uang tebusan sesuai dengan UU Pengampunan No 11 Pajak 2016 akan mampu mendorong wajib pajak membayar pajak dengan benar melalui pengungkapan seluruh harta yang yang belum dilaporkan dalam SPT Tahunan PPh. Tax amesty membebaskan dari pemeriksaan pajak, penyidikan dan penagihan pajak akan mampu membuat wajib pajak membayar pajak penghasilan terutang secara tepat waktu dan memperhitungkan pajak penghasilan sesuai dengan ketentuan perpajakan. Penelitian ini sejalan dengan penelitian yang dilakukan oleh Sari \& Fidiana, menyatakan bahwa bahwa tax amnesty berpengaruh positif terhadap kepatuhan wajib pajak [3]. Serta tidak sejalan dengan penelitian Kusumaningrum \& Aeni, menyatakan bahwa tax amnesty tidak memiliki pengaruh terhadap kewajiban wajib pajak [21].

\section{Kesimpulan, Keterbatasan dan Saran}

\section{Kesimpulan}

Berdasarkan hasil penelitiam yang dilakukan dapat ditarik kesimpulan bahwa:

1. Kesadaran wajib pajak berpengaruh positif terhadap kepatuhan wajib pajak orang pribadi,

2. Sanksi perpajakan berpengaruh positif terhadap kepatuhan wajib pajak orang pribadi.

3. Kualitas pelayanan perpajakan tidak berpengaruh terhadap kepatuhan wajib orang pribadi.

4. Pengetahuan perpajakan berpengaruh positif terhadap kepatuhan wajib orang pribadi.

5. Tax amnesty berpengaruh positif terhadap kepatuhan wajib pajak orang pribadi.

\section{Keterbatasan Penelitian}

Dalam penelitian ini terdapat keterbatasan dalam melakukan penelitian. Keterbatasan dalam penelitian ini antara lain:

1. Nilai Adjusment $R$ Square menunjukan nilai relatif kecil sebesar 41,90 persen. Sehingga masih terdapat variabel lain seperti pelayanan pajak yang mempengaruhi kepatuhan wajib pajak.

2. Penelitian ini menggunakan metode survey (kuesioner) dengan menggunakan google forms yang berpotensi bahwa responden tidak tepat sasaran karena dilakukan secara online atau tidak secara langsung.

\section{Saran}

Berdasarkan kesimpulan yang diperoleh penelitian ini, maka diajukan saran-saran sebagai berikut: 


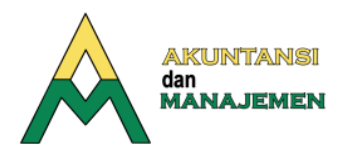

https://akuntansi.pnp.ac.id/jam

e-ISSN 2657-1080, p-ISSN 1858-3687

1. Dalam rangka meningkatkan kepatuhan wajib pajak menjadi lebih baik maka kantor pelayanan pajak harus meningkatkan pemahaman perpajakan dan kesadaran perpajakan agar kewajiban wajib pajak akan meningkat.

2. Bagi wajib pajak untuk selalu mempelajari peraturan perpajakan yang berlaku, sehingga mengikuti perkembangan peraturan perpajakan yang diterapkan di Indonesia.

\section{Implikasi Penelitian}

Berdasarkan hasil penelitian, maka penelitian selanjutnya adalah melakukan penelitian dengan menambahkan variabel yang berpengaruh terhadap kepatuhan wajib pajak orang pribadi seperti sunset policy karena Penghapusan sanksi administrasi ini dirasa oleh wajib pajak sebagai pengurang beban perpajakan yang harus dibayar.

\section{Ucapan Terima Kasih}

Terima kasih penulis ucapkan kepada semua pihak yang telah membantu dan mendukung penelitian ini yaitu wajib pajak orang pribadi di Kantor Pelayanan Pajak (KPP) di Kota Semarang, sehingga penelitian ini dapat berjalan dengan baik dan dapat memberikan hasil yang bermanfaat bagi pengguna.

\section{Referensi}

[1] Anggarini, L. I., Yuesti, A., \& Sudiartana, I. (2019). Pengaruh Penerapan Kebijakan Tax Amnesty, Pengetahuan Perpajakan, Kesadaran Wajib Pajak Dan Sanksi Perpajakan Terhapa Kepatuhan Wajib Pajak Orang Pribadi DI Kantor Pelayanan Pajak Pratama Denpasar Timur. Jurnal Riset Akuntansi, Vol 9, No. 1.

[2] Ariyanto, D., Andayani, G., \& Putri, I. A. (2020). Influence of Justice,Culture and Love of Money Towards Ethical Perception on Tax Evasion, with Gender as Moderating Variable. Journal of Money Laundering Control, 23(1), 245-266.

[3] Sari, V. P., \& Fidiana. (2017). Pengetahuan Tax Amnesty, Pengetahuan Perpajakan Dan Peayanan Fiskus Terhadap Kepatuhan Wajib Pajak. Jurnal Ilmu dan Riset Akuntansi Volume 6, Nomor 2, ISSN : 2460-0585.

[4] Pradana, E. S., \& Dwirandra, A. (2020). Pengaruh Kesadaran Wajib Pajak, Pengetahuan Perpajakan, dan Sanksi Perpajakan Pada Kepatuhan Wajib Pajak UMKM. e-Jurnal Akuntansi, Vol. 30 No. 6, e-ISSN2302-8556.

[5] Ikhsan, M. F. (2020, 12 30). semarang.bisnis.com. Dipetik 02 13, 2021, dari Realisasi Penerimaan Pajak Jateng Melampaui Targer: https://semarang.bisnis.com.

[6] Semarang.bisnis.com. (2020, Desember 30). Realisasi Penerimaan Pajak Jateng Melampaui Target. Dipetik Maret 11, 2021, dari semarang.bisnis.com: 


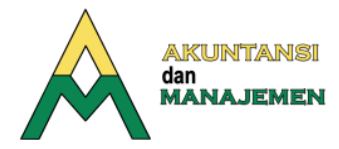

https://akuntansi.pnp.ac.id/jam

e-ISSN 2657-1080, p-ISSN 1858-3687

https://semarang.bisnis.com/read/20201230/536/1336875/realisasi-

penerimaan-pajak-jateng-melampaui-target.

[7] Detik News. (2021, Januari 15). Walkot Semarang Imbau Masyarakat Maksimalkan E-Filing BUat Lapor Pajak. Dipetik Maret 19, 2021, dari news.detik.com: https://news.detik.com/berita/d-5336125/walkot-semarangimbau-masyarakat-maksimalkan-e-filing-buat-lapor-pajak.

[8] Ritonga, P. (2011). Pengaruh Penagihan Pajak dengan Surat Paksa terhadap Kepatuhan Wajib Pajak di Kantor Pelayanan Pajak Pratama Medan Timur. Jurnal Ilmiah Sains dan Komputer. Vol. 11 No. 3, 215-224.

[9] Rahayu, N. (2017). Pengaruh Pengetahuan Perpajakan, Ketegasan Sanksi Pajak, Dan Tax Amnesty Terhadap Kepatuhan Wajib Pajak. Akuntansi Dewantara Vol 1, No. 1, e-ISSN: 2549-9637.

[10] Wibowo, A., Rispantyo, \& Widajanti, E. (2020). Pengaruh Pengetahuan Perpajakan, Kesadaran Wajib Pajak, Kualitas Pelayanan Pajak Dan Sanksi Pajak Terhadap Kepatuhan Wajib Pajak Daerah Lain Kabupaten Ponorogo. Jurnal Manajemen Sumber Daya Manusia Vol. 14, No. 1, 48-62.

[11] Putri, N. E., \& Agustin, D. (2018). Pengaruh Pengetahuan Perpajakan Dan Sanksi Pajak Terhadap Kepatuhan Wajib Pajak Orang Pribadi (Studi Kasus: KPP Pratama Kebayoran Lama Kota Jakarta Selatan). Media Akuntansi Perpajakan Vol. 3, No. 2, ISSN: 2355-9993, 1-9.

[12] Lesmana, D., Panjaitan, D., \& Maimunah, M. (2017). Tax Compliance Ditinjau dari Theory of Planned Behavior (TPB): Studi Empiris Pada Wajip Pajak Orang Pribadi dan Badan yang Terdaftar Pada KPP di Kota Palembang . Jurnal InFestasi Vol. 13 No. 2, 354-366.

[13] Rorong, E. N., Kaangi, L., \& Runtu, T. (2017). Pengaruh Kebijakan Tax Amnesty, Kesadaran Wajib Pajak Dan Sanksi Pajak Terhadap Kepatuhan Wajib Pajak Orang Pribadi Di KPP Pratama Manado. Jurnal Riset Akuntansi Going Concern 12(2), 175 187.

[14] Rahma, A. (2010). Panduan Pelaksanaan Administrasi Perpajakan untuk Karyawan, Pelaku Bisnis dan Perusahaan. Bandung: Nuansa.

[15] Boediono. (2013). Pelayanan Prima Perpajakan. Jakarta: Rineka Cipta.

[16] Gunadi. (2016). Panduan Komprehensif Pajak Penghasilan. Jakarta: Niaga Swadaya.

[17] Waluyo. (2017). Perpajakan Indonesia Edisi 12 Buku 1. Jakarta: Penerbit Salemba Empat.

[18] Ramadhanty, A., \& Zulaikha. (2020). Pengaruh Pemahaman Tentang Perpajakan, Kualitas Pelayanan Fiskus, Sistem Transparansi Perpajakan, Kesadaran Wajib Pajak 
Dan Sanksi Perpajakan Terhadap Kepatuhan Wajib Pajak Orang Pribadi. Diponogoro Journa Of Accounting Volume 9, No. 4. ISSN: 2337-3806, 1-12.

[19] Tjiptono, F., \& Chandra, G. (2012). Pemasaran Strategik. Yogyakarta: Andi Offset.

[20] Listyowati, Samrotun, Y. C., \& Suhendro. (2018). Faktor-Faktor Yang Mempengaruhi Kepatuhan Wajib Pajak Dalam Membayar Pajak. Jurnal Riset Akuntansi Dan Bisnis Airlangga Vol. 3, No. 1.

[21] Kusumaningrum, N. A., \& Aeni, I. N. (2017). Pengaruh Tax Amnesty, Pengetahuan Perpajakan, Dan Kesadaran Perpajakan Terhadap Kepatuhan Wajib Pajak Pada Kantor Pelayanan Pajak (KPP) Pratama Pati. Accounting Global Journal Vol.1,No. 1.

[22] Sugiyono. (2017). Metode Penelitian Kuantitatif, Kualitatif, dan R\&D. Bandung: CV Alfabeta.

[23] Indriantoro, N., \& Supomo, B. (2014). Metodologi Penelitian Bisnis Untuk Akuntansi \& Manajemen. Edisi 1. Cetakan ke-12. Yogyakarta: BPFE.

[24] Ghazali, I. (2018). Aplikasi Analisis Multivariate Dengan Progam IBM SPSS 25. . Semarang: Badan Penerbit Universitas Diponegoro. 